\title{
肺癌に合併する非細菌性血栓性心内膜炎の 特徵と光の意義
}

\author{
Features and Significance of Nonbacterial Thrombotic Endocarditis \\ in Patients with Lung Cancer
}

田村厚久 ${ }^{1,2} \cdot$ 松原 $\quad$ 修 $^{1} \cdot$ 小松彦太郎 ${ }^{2} \cdot$ 毛利昌史 $^{2} \cdot$ 片山 $\quad$ 透 2

要旨: 肺癌患者における非細菌性血栓性心内膜炎 (nonbacterial thrombotic endocarditis: NBTE)の特徵と意義を調べるため, 肺癌剖検142例の臨床病理学的検討を行った。11例 $(7.7 \%)$ にB E Eを認め, 組織型別には腺癌62例中 8 例 (13\%), 扁平上皮癌35例中 3 例 (8.6\%)の順で, 小細胞癌 (34例) にはNBTEの合併はみられなかった。一方142例中11例 に病理学的に播種性血管内血液凝固 (disseminated intravascular coagulation：DIC)が みられた。このうち 4 例 (36\%) はNBTE症例で, DICとNBTEとの間には有意の相関を 認めた $(\mathrm{p}<0.01)$. NBTE 11例中 7 例に全身の血栓塞栓症を認め, その部位は脾 ( 7 例)， 脳 ( 5 例), 腎 ( 4 例), 心 ( 3 例), 腸間膜 ( 2 例) であった。多発性出血性脳梗塞 ( 4 例) は いずれも致命的で，心筋梗塞や腸間膜動脈塞栓症による腹膜炎も死因となっていた。 NBTEは肺癌に稀ならず合併し, それによる血栓塞栓症は予後を左右する事もあるた め, 臨床医はNBTEの特徵と意義を熟知する必要がある.

〔肺癌 $34(6) ： 843 \sim 852,1994 〕$

Key words: Nonbacterial thrombotic endocarditis, Lung cancer,

Disseminated intravascular coagulation, Thromboembolism

\section{緒}

1888年にZeigler ${ }^{1)} よ っ て$ 最初に提唱され, 1936年にGrossとFriedberg ${ }^{2)} に よ っ て$ 命名され た非細菌性血栓性心内膜炎 (nonbacterial thrombotic endocarditis : 以下NBTE) はcachectic endocarditis, marantic endocarditis, あるいはterminal endocarditisとも呼ばれたよ うに, 当初は衰弱した患者の剖検時に偶発的に 認められる所見とみなされていた ${ }^{1) 31}$. しかし 胃癌, 肺癌, 膵癌などの担癌患者において NBTEの存在から脳梗塞や心筋梗塞といった 重篤な全身の塞栓症が派生する事が次第に明ら

1. 東京医科歯科大学医学部病理

2. 国立療養所東京病院呼吸器科
かにされ4), 今日ではNBTEは担癌患者の予後 やquality of lifeを損るる合併症の一つとして 重要視されている5).

ただNBTEに関するこれまでの研究の多く は病理医や循環器科医あるいは神経科医の手に よるものであり ${ }^{1) 77, ~}$ 実際に肺癌のNBTE患者 の診療に携わる呼吸器科医の注目を十分集める には至っていない. 本研究では肺癌患者におけ るNBTEの特徵や意義についての理解を深め る事を目的に, 肺癌剖検症例を用いてNBTEの 臨床病理学的検討を行った.

\section{対象と方法}

1978年から1992年の15年間に東京医科歯科大 
学医学部付属病院で解剖された, 多重癌症例を 除く肺癌症例142例 (男性112例, 女性30例, 平均 63歳)を対象とした.

142例の剖検材料の評価からNBTE合併症例 を見い出し, 肺癌の組織型の確認や臨床像につ いての詳細な解析を行った.

この解析に基づいて，まずNBTE合併例の背 景因子について検討した。血栓形成には一般的 に血液性状の変化, 血管壁性状の変化, 血流の 変化の 3 つの要因が重要とされ8), NBTEの発 生についてもこれと関連して全身的要因として 凝固充進状態が, 局所的要因として弁尖の傷害 が重要視されている9). そこで本研究では全身 的要因として血液凝固異常, 特に播種性血管内 血液凝固 (disseminated intravascular coagulation：DIC)に, 局所的要因として弁膜症, 不 整脈の有無やその他の心臟局所の状態に注目し た.

続いてNBTEの病理所見, NBTEの関連病変 について解析し，それらを対比する事によって 肺癌に合併するNBTEの特徵と意義を検討し た。

統計学的手法は $\chi$ square test, Fischer's exact test, $\mathrm{t}$ testを用い, $\mathrm{p}<0.05$ を有意とした。
Table 1. Incidence of nonbacterial thrombotic endocarditis (NBTE) in patients with lung cancer.

\begin{tabular}{lcc}
\hline \multicolumn{1}{c}{ Histologic type } & $\begin{array}{c}\text { No. of cases } \\
\text { with NBTE }(\%) \text { total cases }\end{array}$ \\
\hline Adenocarcinoma & $8(13)$ & 62 \\
Squamous cell carcinoma & $3(8.6)$ & 35 \\
Small cell carcinoma & $0(0)$ & 34 \\
Others & $0(0)$ & 11 \\
\hline \multicolumn{1}{c}{ Total } & $11(7.7)$ & 142 \\
\hline
\end{tabular}

\section{結 果}

\section{NBTEの頻度}

肺癌剖検 142 例中11例 (7.7\%)の心臟に

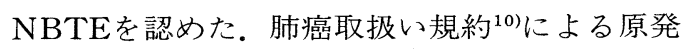
巣の組織型分類では腺癌62例中 8 例 $(13 \%)$, 扁 平上皮癌35例中 3 例 $(8.6 \%)$ にNBTEがみられ たのに対し, 小細胞癌 34 例, その他 11 例 (大細胞 癌10例, 腺扁平上皮癌 1 例)にはNBTEがみら れず，有意差はないものの腺癌にNBTE合併が 多い傾向を認めた (Table 1).

\section{NBTE症例の詳細と背景因子}

NBTE症例の詳細をTable 2に示す. 男性 8 例, 女性 3 例, 平均年齢は57歳で, NBTE合併例 と非合併例の間に性差，年㱓差を認めなかった。

Table 2. Patient characteristics.

\begin{tabular}{|c|c|c|c|c|c|c|c|c|c|}
\hline \multirow{2}{*}{$\begin{array}{l}\text { Case } \\
\text { no. }\end{array}$} & \multirow[b]{2}{*}{ Sex } & \multirow[b]{2}{*}{ Age } & \multirow{2}{*}{$\begin{array}{l}\text { Histologic } \\
\text { type of } \\
\text { lung cancer }\end{array}$} & \multicolumn{2}{|l|}{ Systemic conditions } & \multicolumn{4}{|c|}{ Cardiovascular conditions } \\
\hline & & & & Major symptoms & $\mathrm{DIC}^{+}$ & $\begin{array}{l}\text { Underlying } \\
\text { disease }\end{array}$ & $\begin{array}{l}\text { Cardiac } \\
\text { murmur }\end{array}$ & $\begin{array}{l}\text { Pericarditis } \\
\text { carcinomatosa }\end{array}$ & $\begin{array}{l}\text { Irradiation to } \\
\text { the mediastinum }\end{array}$ \\
\hline 1 & M & 37 & Ad. (w.d.) & Brain edema $(\mathrm{m})$. & + & - & - & + & - \\
\hline 2 & $\mathrm{~F}$ & 77 & Ad. (w.d.) & Brain edema (a.) & + & HT & - & - & - \\
\hline 3 & $\mathrm{M}$ & 61 & Ad. (p .d.) & Brain edema (a.) & + & - & + & + & + \\
\hline 4 & M & 68 & Ad. (w.d.) & Brain edema (a.) & + & - & + & - & - \\
\hline 5 & $\mathrm{~F}$ & 61 & Ad. (w.d.) ${ }^{*}$ & Brain edema $(\mathrm{m})$. & - & - & - & - & - \\
\hline 6 & $\mathrm{M}$ & 43 & Ad. (p .d.) & $\begin{array}{l}\text { Brain edema (a., m.) } \\
\text { /Peritonitis }\end{array}$ & - & - & - & - & + \\
\hline 7 & $\mathrm{M}$ & 60 & Ad. (m.d.) & Lymphangitis ** & - & - & + & + & - \\
\hline 8 & $\mathrm{~F}$ & 65 & Ad. (p .d.) & Radiation pneumonitis & - & - & - & + & + \\
\hline 9 & M & 50 & S q. (m.d.) & Intestinal bleeding & + & - & - & + & + \\
\hline 10 & $\mathrm{M}$ & 51 & S q. (m.d.) & Cancerous cachexia & - & - & - & - & - \\
\hline 11 & $\mathrm{M}$ & 57 & Sq. (p .d.) & Cancerous cachexia & - & - & - & - & + \\
\hline
\end{tabular}

M: male, F: female, Ad.: adenocarcinoma, Sq.: squamous cell carcinoma, w.d.: well differentiated, m.d.: moderately differentiated, p.d.: poorly differentiated, a.: apoplexy, m.: metastasis, HT: hypertension, ${ }^{+}$: clinically diagnosed disseminated intravascular coagulation (DIC), *: a case with marked mucin production, ${ }^{* *}$ : pulmonary lymphangitis carcinomatosa. 
Fig. 1. Microscopic findings of the lung in Case 5. The primary site shows well differentiated adenocarcinoma with marked mucin production (hematoxylin and eosin stain, $\times 130$ ).

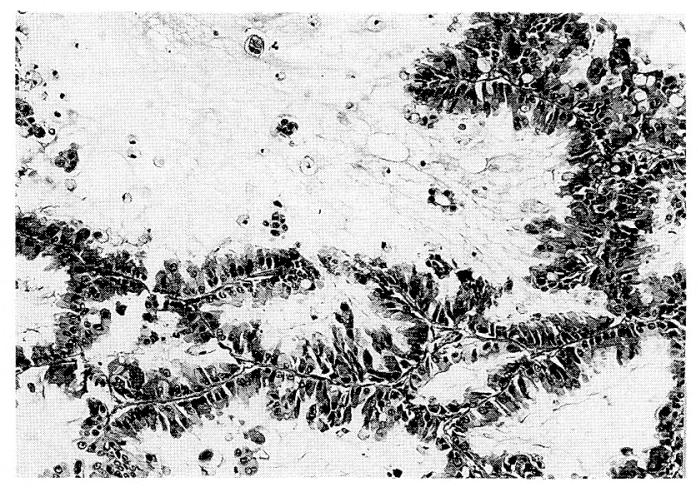

腺癌は高分化型腺癌 4 例, 中分化型腺癌 1 例, 低分化型腺癌 3 例であった。このうち 1 例はい わゆる粘液結節型10)のもので, 原発巣の癌胞巣 に粘液産生が高度にみられた(Fig. 1)が, 他の 症例の原発巣には高度の粘液産生はみられなか つた。な扮扁平上皮癌の分化度は中分化型 2 例, 低分化型 1 例であった。

主たる臨床症状としては脳浮腫状態が 6 例に みられ，うち 4 例は脳血管障害(いずれも出血性 脳梗塞)によるものと考えられていた。

全身の血液凝固異常については11例中 5 例で は臨床的にDICの状態にあると診断されていた。 ただ臨床的なDICは病理診断によるDICとは必

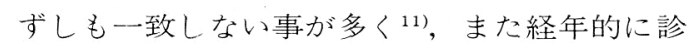
断基準が変更する事や治療による修飾を受ける 事から, 剖検時のNBTEという病理所見と対比 させるには剖㭘時の病理学的なDICの方がより 適切と考之た。以上より以後の本研究のDICと はNBTEとDICの関係をみたKimらの病理学的 な定義 ${ }^{12)}$ に従い, “小血管, 毛細血管にde novo と考えられる多発性微小フィブリン血栓を認め るもの”(Fig. 2)とし，これによってDICによる 血栓とNBTEに由来する古典的な血栓とを区 別した。この定義を満なすDIC症例は142例中11 例で，うち 4 例 (36\%) がNBTE症例であった。 そこでNBTEとDICの関係をみるとDIC合併例 は非合併例に比して有意にNBTE合併が多く
Fig. 2. Microscopic findings of the kidney in Case 3. Multiple fibrin thrombi in the glomerular capillaries (arrowheads). Based on anatomic interpretation, the thrombi were considered to be formed de novo (hematoxylin and eosin stain, $x$ 330).

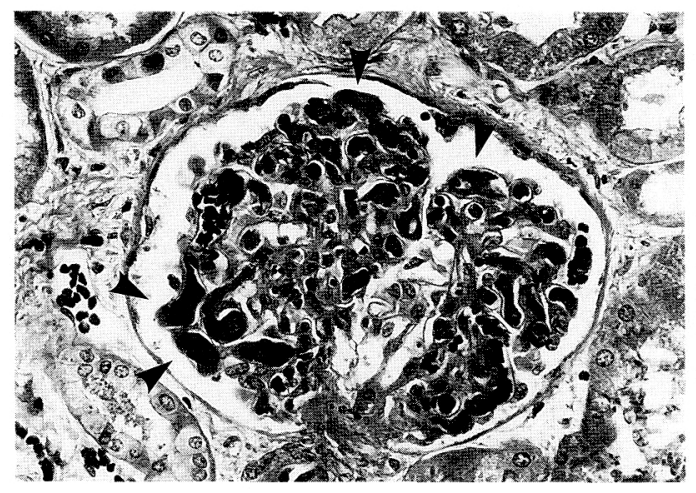

Table 3. Disseminated intravascular coagulation (DIC) and nonbacterial thrombotic endocarditis (NBTE).

\begin{tabular}{lcc}
\hline & $\begin{array}{l}\text { No. of cases } \\
\text { with NBTE }(\%) \#\end{array}$ & $\begin{array}{l}\text { No. of } \\
\text { total cases }\end{array}$ \\
\hline $\begin{array}{l}\text { No. of cases } \\
\text { with DIC }\end{array}$ & $3^{*} / 4^{* *}(43 / 36)$ & $7 / 11$ \\
$\begin{array}{l}\text { No. of cases } \\
\text { without DIC }\end{array}$ & $5 * / 7^{* *}(9.1 / 5.3)$ & $55 / 131$ \\
\hline \#: cases of adenocarcinoma/all cases of lung cancer, \\
+ : pathologically proved DIC, ${ }^{*} \mathrm{p}<0.05, \quad{ }^{* *} \mathrm{p}<0.01$.
\end{tabular}

$(\mathrm{p}<0.01)$, 腺癌症例に限ってみてもDIC合併例 は非合併例に比して有意にNBTE合併が多か つた $(\mathrm{p}<0.05)$ (Table 3).

局所的要因である心臓の状況について，まず 基礎疾患は高血圧症を 1 例にみたのみであり， 弁膜症患者, 経過中治療を要する不整脈を示し た患者, 心臓カテーテル検査施行歴のある患者 はいなかった。他方, 癌性心囊炎を 5 例に認め, 縦隔を照射野に含む放射線療法もまた 5 例で行 われていたため, これらの所見とNBTE合併に ついての関係をみた (Table 4, 5).しかしこれ らの局所的因子の有無とNBTEの合併には有 意の相関はなかった。

なお 11 例中 3 例では明らかな収縮期心雑音が 聴取されていたが, 死亡前 1 力月以内に心臓超 音波検查が施行された 4 例(症例 $1,5,6,7$ ) 
Table 4. Pericarditis carcinomatosa and nonbacterial thrombotic endocarditis (NBTE).

\begin{tabular}{lcc}
\hline & $\begin{array}{l}\text { No. of cases } \\
\text { with NBTE }(\%) \#\end{array}$ & $\begin{array}{l}\text { No. of } \\
\text { total cases } \#\end{array}$ \\
\hline $\begin{array}{l}\text { No. of cases } \\
\text { with pericarditis } \\
\text { carcinomatosa }\end{array}$ & $4 / 5(18 / 13)$ & $22 / 40$ \\
$\begin{array}{l}\text { No. of cases } \\
\text { without pericarditis }\end{array}$ & $4 / 6(10 / 5.9)$ & $40 / 102$ \\
carcinomatosa &
\end{tabular}

\#: cases of adenocarcinoma/all cases of lung cancer.

Table 6. Features of nonbacterial thrombotic endocarditis.

\begin{tabular}{rllc}
\hline $\begin{array}{c}\text { Case } \\
\text { no. }\end{array}$ & Location & Number & Size $(\mathrm{mm})$ \\
\hline 1 & AV, MV & multiple & $<5$ \\
2 & AV & single & $5-10$ \\
3 & AV, MV & multiple & $10<$ \\
4 & MV & single & $10<$ \\
5 & MV & single & $<5$ \\
6 & MV & multiple & $5-10$ \\
7 & AV & multiple & $<5$ \\
8 & AV & multiple & $5-10$ \\
9 & MV, LA & multiple & $5-10$ \\
10 & TV & single & $5-10$ \\
11 & AV & single & $5-10$ \\
\hline
\end{tabular}

AV: aortic valve, MV: mitral valve, TV: tricuspid valve, LA: left atrium.

を含め，生前にvegetationすなわち血栓性病贅 が確認されていた症例はなかった。

\section{NBTEの病理}

剖検時にみられたNBTEの特徵をTable 6に 示す.Vegetationの部位は大動脈弁と僧帽弁が 同数で大半を占めた。大きさは $5 \mathrm{~mm}$ 未満 3 例, 5 10 mm 6 例, $10 \mathrm{~mm}$ 以上 2 例で, 1 個のもの が 5 例， 2 個以上のものが 6 例であった。

NBTEの肉眼像をFig. 3に, 顕微鏡像をFig. 4 に示す.大きさの如何に関わらず, vegetationは もろく，組織学的には硝子化を伴うフィブリン と僅かな血小板, 赤血球から成り, 他の細胞成 分に乏しいものであった。なお $10 \mathrm{~mm}$ 以上の大 きなvegetationでは基底部にのみ器質化の所見 がみられた。
Table 5. Irradiation to the mediastinum and nonbacterial thrombotic endocarditis (NBTE).

\begin{tabular}{|c|c|c|}
\hline & $\begin{array}{l}\text { No. of cases } \\
\text { with NBTE }(\%) \#\end{array}$ & $\begin{array}{l}\text { No. of } \\
\text { total cases }=\end{array}$ \\
\hline $\begin{array}{l}\text { No. of cases } \\
\text { with irradiation } \\
\text { to the mediastinum }\end{array}$ & $3 / 5(30 / 11)$ & $10 / 45$ \\
\hline $\begin{array}{l}\text { No. of cases } \\
\text { without irradiation } \\
\text { to the mediastinum }\end{array}$ & m $5 / 6(9.6 / 6.2)$ & $52 / 97$ \\
\hline
\end{tabular}

\#: cases of adenocarcinoma/all cases of lung cancer.

Fig. 3. Gross findings of nonbacterial thrombotic endocarditis in Case 7 (A) and Case 4 (B). (A) Small thrombotic vegetations on the aortic valve (arrowheads). (B) A large thrombotic vegetation on the mitral valve (arrowhead).

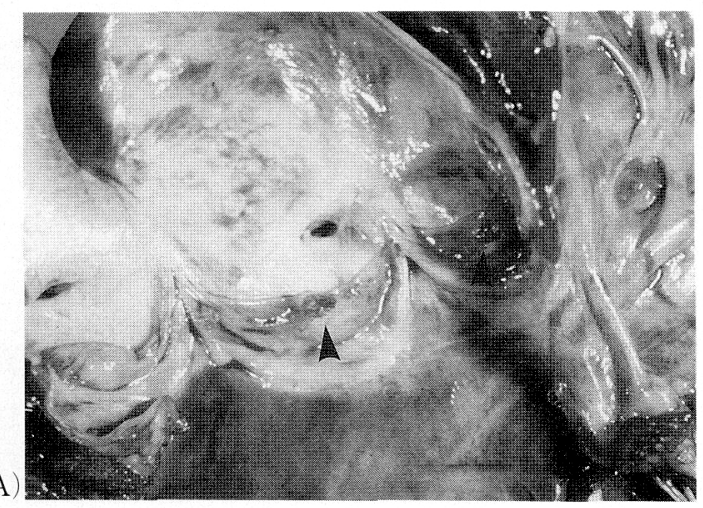

B)

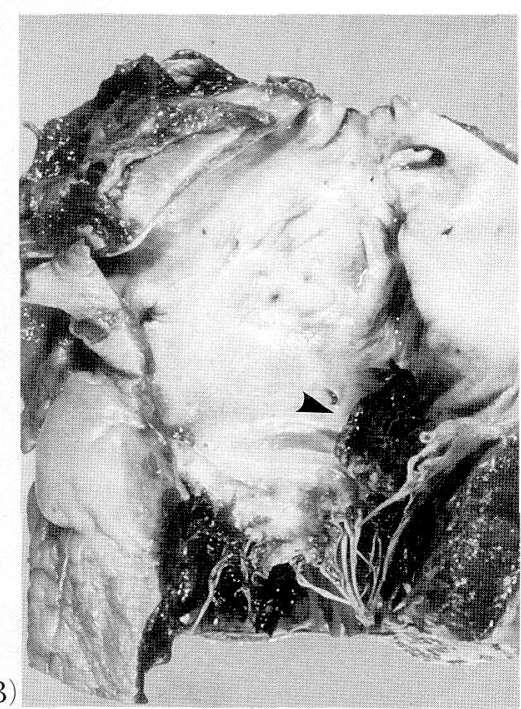


Fig. 4. Microscopic findings of nonbacterial thrombotic endocarditis in Case 1 (A) and Case $4((\mathrm{~B})$ and $(\mathrm{C}))$. (A) A small vegetation consisting of blood component without inflammatory cells (hematoxylin and eosin stain, $\times 17$ ). (B) A large vegetation also consisting of blood components. Note organization (arrowhead) at the base (hematoxylin and eosin stain, $\times 2$ ). (C) Abundant fibrin deposition (arrowheads) on the surface of the vegetation (phosphotungstic acid hematoxylin stain, $\times 130$ ).

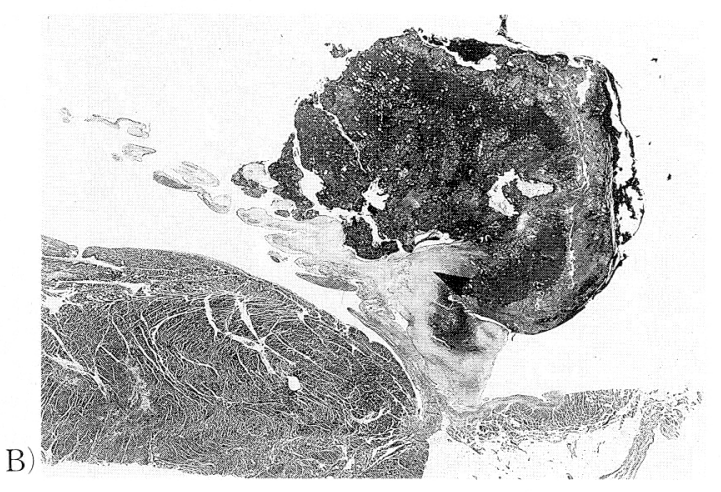

A)
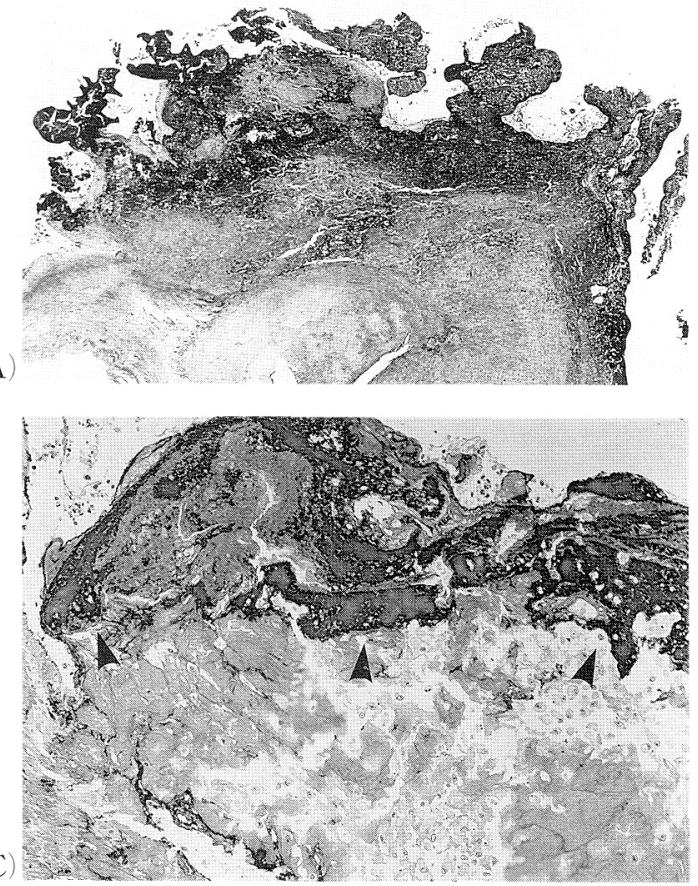

Table 7. Pathologic findings associated with nonbacterial thrombotic endocarditis (NBTE).

\begin{tabular}{|c|c|c|c|c|c|c|c|c|}
\hline \multirow{2}{*}{$\begin{array}{l}\text { Case } \\
\text { no. }\end{array}$} & \multicolumn{5}{|c|}{ Thromboembolism/Infarction in systemic organs } & \multirow{2}{*}{$\begin{array}{l}\text { Deep } \\
\text { vein } \\
\text { thrombosis }\end{array}$} & \multirow{2}{*}{$\mathrm{DIC}^{+}$} & \multirow{2}{*}{ NBTE-related death } \\
\hline & Brain & Heart & Kidney & Spleen & Mesentery & & & \\
\hline 1 & $\mathrm{NE}$ & - & $+\gamma-$ & $+r-$ & - & - & + & No \\
\hline 2 & $+>+$ & $+Y-$ & $+\gamma+$ & $+\gamma+$ & - & - & + & Yes \\
\hline 3 & $+/+$ & - & $+/+$ & $+\gamma+$ & - & + & + & Yes \\
\hline 4 & $+/+$ & $++/+$ & - & $+/+$ & - & + & - & Yes \\
\hline 5 & - & - & - & - & - & + & - & No \\
\hline 6 & $+>+$ & - & - & $+\quad+$ & $+>+$ & - & - & Yes \\
\hline 7 & - & - & - & - & - & - & - & No \\
\hline 8 & $\mathrm{NE}$ & - & - & - & - & + & - & No \\
\hline 9 & $+/+$ & ++ & $+<+$ & $+/+$ & $+/-$ & - & + & No \\
\hline 10 & - & - & - & - & - & - & - & No \\
\hline 11 & - & - & - & $+/-$ & - & & - & No \\
\hline
\end{tabular}

pathologically proved disseminated intravascular coagulation (DIC), NE: not examined,

$\square$ : direct cause of death.

\section{NBTEによる血栓塞栓症}

剖検時におけるNBTE関連病変をTable 7に 示子. NBTE 11例中全身への塞栓症がみられた のは7 例，みられなかったのは 4 例であった。 塞栓症のみられた臟器は脾臓が 7 例と最も多く, 以下脳，腎，心，腸間膜之続き(Fig. 5)，ほとん
どの場合梗塞を伴っていた。脳梗塞はいずれの 症例においても多発性で，4例恔抯性梗塞を 伴うか伴わ好出血性梗塞を，1例は貧血性梗塞 を呈していた。血栓塞栓症を直接死因としてい た 4 例はいずれも多発性出血性脳梗塞の症例で (Fig. 6)，うち 2 例では他藏器への)塞栓症 (心筋 
Fig. 5. Microscopic findings of thromboembolism in systemic organs in Case 3 (A) and Case 6 (B). (A) An organizing thrombus in a branch of the middle cerebral artery (hematoxylin and eosin stain, $\times 42$ ). (B) A fresh thrombus in a branch of the superior mesenteric artery. Note fibrin deposition on the surface of the thrombus (arrowheads) (phosphotungstic acid hematoxylin stain, $X$ 17).
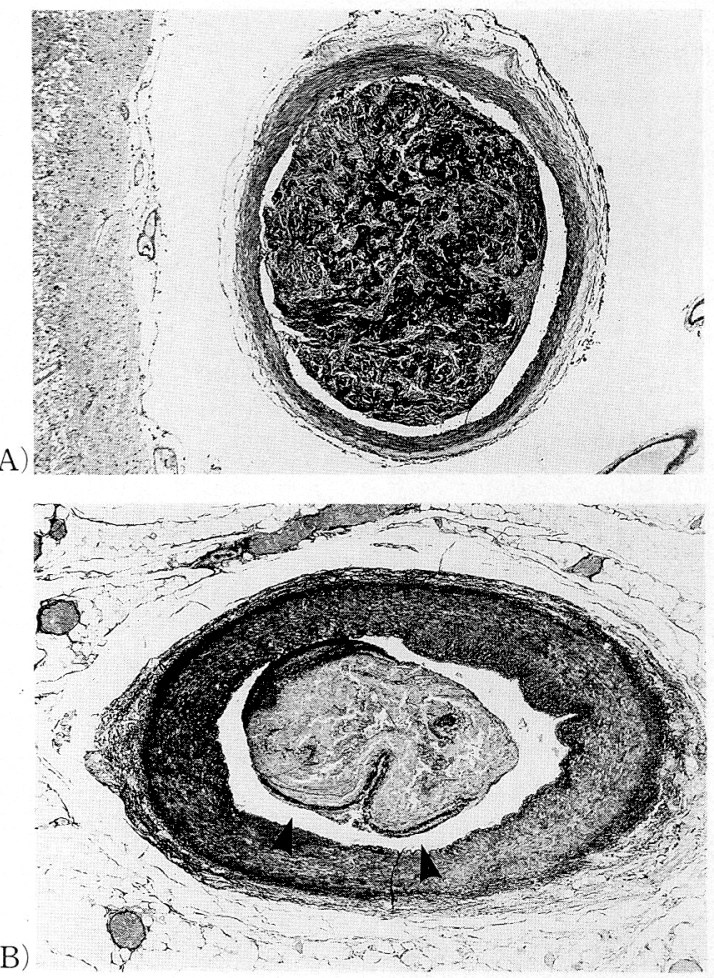

梗塞 1 例，腸間膜動脈への塞栓に基づく穿孔性 腹膜炎 1 例)も死因となっていた (Fig. 7)。この 他前述の如く DICを 4 例に, 深部静脈血栓 (中心 静脈栄養カテーテル部の血栓を除く)を 4 例に 認めた。肺血栓塞栓症は 4 例にみられたが, 三 尖弁にvegetationが存在した症例10には肺血栓 塞栓症を認めなかった。なお11例の脳底部の動 脈や冠状動脈の粥状硬化は高血圧症を有してい た症例 2 を除き，いずれも軽微なものであった。 塞栓症の有無及び程度と NBTEの大きさと の関係をみると, vegetationの大きさが $10 \mathrm{~mm}$ 以上の症例 3,4 では広範な全身への塞栓症が みられ直接死因となっていたのに対し, vege-
Fig. 6. Gross findings of the multiple, hemorrhagic cerebral infarction (arrowheads) in Case 3.

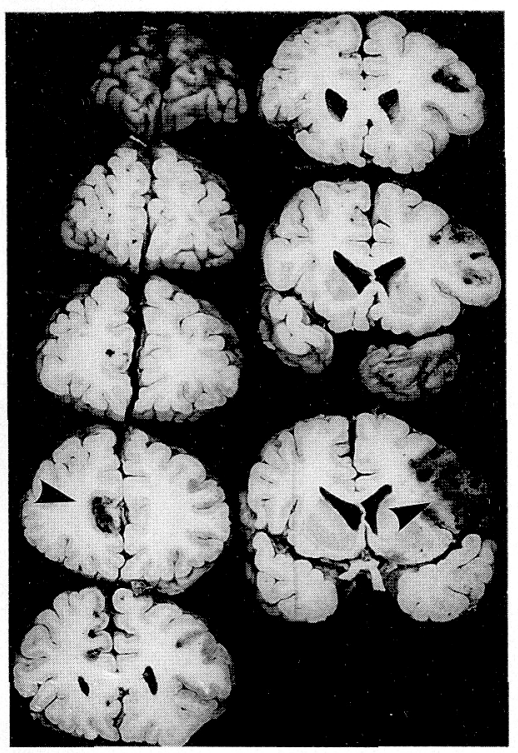

Fig. 7. (A) Microscopic findings of the heart in Case 4. Acute myocardial infarction accompanied by inflammatory cells at the apex (hematoxylin and eosin stain, $x$ 130). (B) Gross findings of the small intestine in Case 6 showing perforating peritonitis (arrowheads).
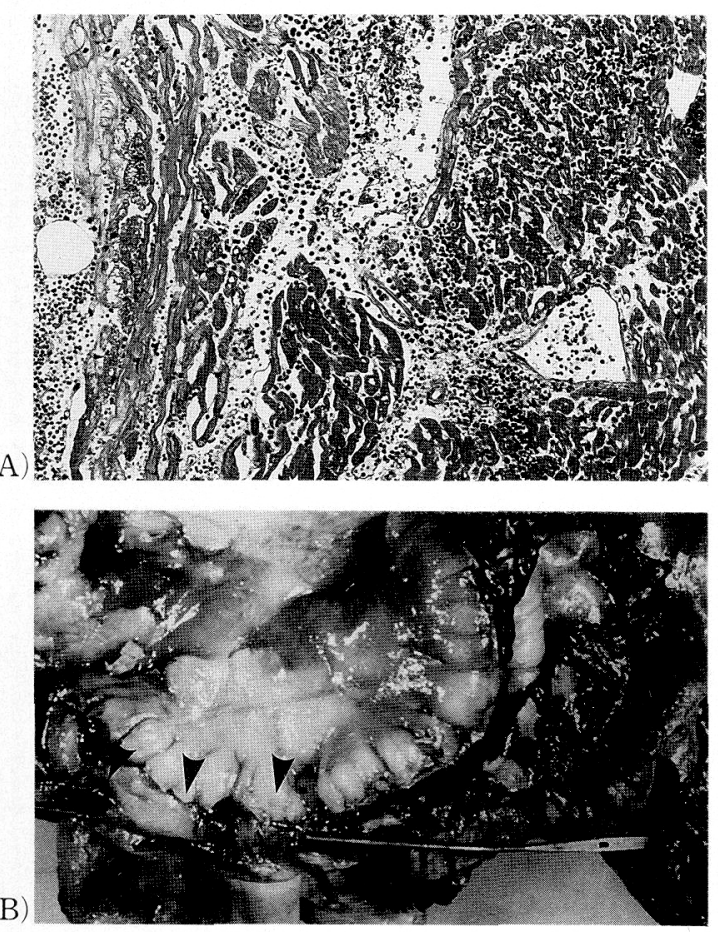
Table 8. Incidence of nonbacterial thrombotic endocarditis (NBTE) in previous reports.

\begin{tabular}{|c|c|c|c|c|}
\hline Authors & Objects & No. of total cases & $\begin{array}{l}\text { No. of cases } \\
\text { with NBTE }\end{array}$ & Incidence $(\%)$ \\
\hline \multirow[t]{2}{*}{ Rosen et al. ${ }^{16}(1973)$} & Bronchiolar carcinoma of the lung & 116 & 9 & 7.7 \\
\hline & Adenocarcinoma of the lung & 112 & 8 & 7.1 \\
\hline Chino et al. ${ }^{17}(1975)$ & $\begin{array}{l}\text { Malignant neoplasm of larynx, } \\
\text { trachea, bronchus, and lung }\end{array}$ & 178 & 6 & 3.4 \\
\hline \multirow[t]{3}{*}{ Deppisch et al. ${ }^{18}(1976)$} & Adenocarcinoma of the lung & 112 & - & 4.5 \\
\hline & Anaplastic carcinoma of the lung & 70 & - & 2.8 \\
\hline & Squamous cell carcinoma of the lung & 40 & - & 0 \\
\hline Kuramoto et al. ${ }^{19}(1984)$ & Lung cancer & - & 28 & 13 \\
\hline \multirow[t]{4}{*}{ Present study } & Lung cancer & 142 & 11 & 7.7 \\
\hline & Adenocarcinoma of the lung & 62 & 8 & 13 \\
\hline & Squamous cell carcinoma of the lung & 35 & 3 & 8.6 \\
\hline & Small cell carcinoma of the lung & 34 & 0 & 0 \\
\hline
\end{tabular}

tationの大きさが $5 \mathrm{~mm}$ 以下の 3 例中 2 例 (症 例 5,7 ) では全身への塞栓症は起こっていなか った。

\section{考察}

肺癌患者にみられる心血管病変には癌そのも のによるものとよらないものがある5). 前者の 代表は心転移, 特に癌性心囊炎であり, それが 臨床的に明確に認識できるものである事やその 頻度が剖検例で30\%に達する程高い事などから， これまで多くの臨床病理学的な検討が行われて いる13) 15). しかし後者の代表であるNBTEはほ とんどの場合生前診断されず剖検で初めて診断 されるものであるため, 肺癌の臨床像との関係 は明確にされていない。

全剖検例の約 1 2\%に認められるという NBTEのうち約半数の症例の基礎疾患は悪性 腫瘍で, 肺癌はその中で萃癌, 胃癌, 乳癌, 前 立腺癌などと並んで重要な位置を占めている Table $8^{16) \sim 19)}$ に肺癌におけるNBTEの頻度につ いてのこれまでの報告を示すが, 今回の肺癌全 体の $7.7 \%$, 肺腺癌の $13 \%$ という数字はKuramotoら ${ }^{19)} の$ 報告に次ぐ高いもので, 肺癌患者の 診療においてNBTEの認識が大変重要である 事を示唆するものであるといえる.

NBTE発生の要因としてかっては弁尖の変
化, 変性が最も重要視され, Grossら ${ }^{2)}$ はBTE

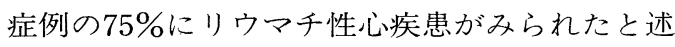
べている。しかし現在では心蔵カテーテル検査 による弁尖の傷害に基づくNBTEの発症が指 摘されてはいる20)ものの，悪性腫瘍患者におけ るNBTEについては全身的なhypercoagulable state, 特にDICとの関連を示唆する報告が多 (12),18),19). 我々のNBTE症例でも弁膜症，不整 脈, 心臓力テーテル検査といった局所的因子を 有するものはなく, さらに癌性心囊炎の存在や 縦隔への照射の関与も明らかでなかったのに対 し，DICとNBTEの間には有意の相関を認めた。 以上より他家の報告同様，肺癌患者における NBTEの発生には心局所の状況よりもDICが重 要と考えられる。

なお以前より NBTEの発生と粘液産生腺癌 との間には密接な関係がある事が強調されてお $\eta^{21) 23)}$, Min ${ }^{23)}$ はNBTEのvegetation内や患 者血中に粘液様物質の存在をみたとすら述べて いる.しかし今回の検討では扁平上皮癌でも 8.6 \%にNBTEがみられ, また腺癌の原発巣の組織 像で粘液産生が高度に認められたのは腺癌 8 例 中 1 例に過ぎなかった. 以上より肺癌患者の診 療において原発巣の生検診断等で粘液産生の高 度な腺癌が認められなくとも, NBTE発生の危 険性は損なわれていない事を銘じておく必要が 


$$
\text { あろう。 }
$$

NBTEは通常大動脈弁か僧帽弁に存在する が, フィブリンと赤血球，血小板からのみ成る ため剝離しやすく, 約半数の症例では脳, 心, 腎, 脾, 腸間膜などへの血栓塞栓症が起こると いわれる ${ }^{9}$. 今回の検討でも半数以上の症例で 血栓塞栓症がみられた。その部位としては脾, 脳, 腎が多く, 予後的には多発性出血性梗塞の 形をとる脳への塞栓症が最も重篤で, 心, 腸間 膜への塞栓症も予後を左右し得るものであった。

Grausら ${ }^{24)}$ は癌患者における脳梗塞について 検討し, 粥状硬化による梗塞は頻度的には多い ものの症状に乏しく，死因となる事も少ないの に対し，NBTEによる脳梗塞の多くは有症状 で，半数では死亡に寄与していたと述べている. 我々の症例でもNBTEの脳梗塞は多発性, 出血 性で重篤なものが多かった。こうした所見は NBTEに基づく脳梗塞の特徵として重要視す る必要がある。

一方担癌患者における心筋梗塞の多くもまた 粥状硬化によるものである25). しかしまれには

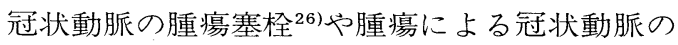
圧迫 ${ }^{15)}$ から筋梗塞が起こる事があり，こうし た場合の梗塞はしばしば直接死因となる。 NBTEによる冠状動脈の血栓塞栓症から起こ る心筋梗塞もまた重篤な事が多いとされ， Fayemiら ${ }^{27)}$ はBTEに基づく心筋梗塞 6 例の うち 3 例は心筋梗塞を死因としていたと指摘し ている. 我々の症例でも冠状動脈に血栓塞栓症 のみられた 3 例のうち 1 例で死因となる心筋梗 塞が起こっていた，肺癌患者における心筋梗塞 に際しては, 腫瘍関連の心筋梗塞に加えて NBTEに基づく心筋梗塞の可能性についても
考慮する必要があると考えられる.

またNBTEも含め, 弁膜疾患によって起こる 腸間膜動脈への血栓塞栓症はしばしば腸管の貫 璧性壊死から穿孔性腹膜炎と進むといわれる ${ }^{28)}$. 我々の症例でもこうした所見がみられており， 肺癌患者における急性腹症, 特に腹膜炎の際に は腸管への転移によるもの ${ }^{29} の$ 他，まれではあ るが, NBTEに基づく腸間膜動脈血栓塞栓症も 鑑別に加えるべきであろう.

なお今回の検討では致命的塞栓症のみられた NBTE症例のvegetationには大きなものが多く， 塞栓症のみられなかったNBTE症例のvegetationは小さなものが多かった. vegetationの 小さい間のNBTEは臨床的に意義の乏しい，い わゆるterminal endocarditis ${ }^{3)}$ の位置にとどま る事が多く, 時間の経過と共にvegetationが大 きくなるにつれて, その剥離しやすさ故血栓塞 栓症の危険性が増すという事は自明の事とはい え，忘れてはならないNBTEの特徵と言えよ j.

かつて McKay ${ }^{30}$ はNBTEの臨床像の 3 徵と して 1) NBTEを起こしやすい病態，2）心雑音， 3) 全身の塞栓症状の 3 つを指摘したが, 進行あ るいは末期肺癌患者の診療においてはこの当り 前のような徵候への注目がややもするとおろそ かになりがちである。しかし仮に末期医療では あっても，NBTEによる血栓塞栓症によって患 者の予後やquality of lifeが大きく損なわれる 事がある以上，これらの徴候への注意を忘れる 事なく，さらにできればvegetationが大きくな り塞栓症が起こりやすくなる前にNBTEの早 期診断を得ようとする姿勢が臨床医にとって大 切な事ではないかと考えられる。

\section{文 献}

1) Zeigler $R$ : Uber den bau die entstehung en620-640, 1936. docaritischer efflorescenzen. Werh Dtsch Kong. Intern Med $7:$ 399, 1888.

2) Gross L, Friedberg CK : Nonbacterial thrombotic endocarditis. Classification and general description. Arch Intern Med 58:

3) Libman $E$ : Characterization of various forms of endocarditis. JAMA $80: 813-818$, 1923.

4) MacDonald RA, Robbins SL: The significance of nonbacterial thrombotic endocar- 
ditis. An autopsy and clinical study of 78 cases. Ann Intern Med 46:255-273, 1957.

5) Rosenthal DS, Braunwald E : HematologicalOncological Disorders and Heart Disease, In : Braunwald E eds. Heart Disease, A Textbook of Cardiovascular Medicine, 4th ed, W.B. Saunders Company, Philadelphia, pp1752-1754, 1992.

6) Lopez JA, Fishbein MC, Siegel RJ : Echocardiographic features of nonbacterial thrombotic endocarditis. Am J Cardiol 59 : 478480, 1987.

7) Kooiker JC, MacLean JM, Sumi SM : Cerebral embolism, marantic endocarditis, and cancer. Arch Neurol 33 : 260-264, 1976.

8）小池盛雄, 横山 武：血栓症, 現代の病理学(総 論）編集, 横山 武, 福西 亮, 綿貫 勤, 他，第 2 版，金原出版，東京，151-162頁 1988 .

9) Lopez JA, Ross RS, Fishbein MC, et al: Nonbacterial thrombotic endocarditis. A review. Am Heart J 113：773-784, 1987.

10）日本肺癌学会編：肺癌取扱い規約，第 3 版，金 原出版, 東京, 1987.

11）田中健蔵：播種性血管内凝固症候群 (DIC), 現 代病理学大系18A 編集, 飯島宗一, 石川栄世, 影山圭三, 他, 中山書店, 東京, 373-388頁 1989 .

12) Kim HS, Suzuki M, Lie JT, et al: Nonbacterial thrombotic endocarditis (NBTE) and disseminated intravascular coagulation (DIC). Autopsy study of 36 patients. Arch Pathol Lab Med 101 : 65-68, 1977.

13) Bisel HF, Wroblewski F, LaDue JS : Incidence and clinical manifestations of cardiac metastases. JAMA $153: 712-715,1953$.

14) Strauss BL, Matthews MJ, Cohen $\mathrm{MH}$, et al: Cardiac metastases in lung cancer. Chest $71:$ 607-611, 1977.

15) Tamura A, Matsubara O, Yoshimura $\mathrm{N}$, et al : Cardiac metastasis of lung cancer. A study of metastatic pathways and clinical manifestations. Cancer $70:$ 437-442, 1992.

16) Rosen $P$, Armstrong $D$ : Nonbacterial thrombotic endocarditis in patients with malignant neoplastic diseases. Am J Med 54:23-29, 1973.

17) Chino F, Kodama A, Otake M, et al : Non- bacterial thrombotic endocarditis in a Japanese autopsy sample. A review of eighty cases. Am Heart J 90 : 190-198, 1975.

18) Deppisch LM, Fayemi AO : Non-bacterial thrombotic endocarditis. Clinicopathologic correlations. Am Heart J 92 : 723-729, 1976.

19) Kuramoto $K$, Matsushita $S$, Yamanouchi $\mathrm{H}$ : Nonbacterial thrombotic endocarditis as a cause of cerebral and myocardial infarction. Jpn Circul J 48: 1000-1006, 1984.

20) Lange HW, Galliani CA, Edwards JE : Local complications associated with indwelling Swan-Ganz catheters. Autopsy study of 36 cases. Am J Cardiol 52 : 1108-1111, 1983.

21) Rohner RF, Prior JT, Sipple JH : Mucinous malignancies, venous thrombosis and terminal endocarditis with emboli. A syndrome. Cancer 19:1805-1812, 1966.

22) RayChaudhuri $M:$ Non-bacterial thrombotic endocarditis in association with mucussecreting adenocarcinomas. Brit $\mathrm{J}$ Dis Chest 65: 98-104, 1971.

23) Min KW, Gyorkey F, Sato C: Mucinproducing adenocarcinomas and nonbacterial thrombotic endocarditis. Pathogenetic role of tumor mucin. Cancer $45: 2374-2382$, 1980.

24) Graus F, Rogers LR, Posner JB : Cerebrovascular complications in patients with cancer. Medicine 64:16-35, 1985.

25) Stewart JR, Fajardo LF : Cancer and coronary artery disease. Int J Radiat Oncol Biol Phys 4 : 915-916, 1978.

26) Ackermann DM, Hyma BA, Edwards WD : Malignant neoplastic emboli to the coronary arteries. Report of two cases and review of the literature. Hum Pathol 18:955-959, 1987.

27) Fayemi AO, Deppisch LM : Coronary embolism and myocardial infarction associated with nonbacterial thrombotic endocarditis. Am J Clin Pathol 68 : 393-396, 1977.

28) Grendell JH, Ockner RK : Vascular diseases of the bowel, In : Sleisenger MH, Fordtran JS eds : Gastrointestinal Disease, 4th ed, W. B. Saunders Company, Philadelphia, 
pp1910-1913, 1989.

29) McNeill PM, Wagman LD, Neifeld JP:

Small bowel metastases from primary carcinoma of the lung. Cancer $59: 1486-1489$,
1987.

30) McKay DG, Wahler GH Jr : Disseminated thrombosis in colon cancer. Cancer $8: 970-$ 978, 1955.

（原稿受付 1994 年 3 月 16 日 /採択 1994 年 6 月 9 日）

\title{
Features and Significance of Nonbacterial Thrombotic Endocarditis in Patients with Lung Cancer
}

\author{
Atsuhisa Tamura, ${ }^{1,2}$ Osamu Matsubara ${ }^{1}$, Hikotaro Komatsu ${ }^{2}$, \\ Masashi Mohri and Toru Katayama ${ }^{2}$
}

1) Department of Pathology, Faculty of Medicine,

Tokyo Medical and Dental University,

2) Department of Respiratory Disease,

National Tokyo Chest Hospital

To examine features and significance of nonbacterial thrombotic endocarditis (NBTE) in patients with lung cancer, we clinicopathologically reviewed 142 autopsied patients with lung cancer. Eleven $(7.7 \%)$ of the patients had NBTE. Incidence of NBTE was $13 \%$ ( $8 / 62$ cases) in adenocarcinoma and $8.6 \%$ (3/35 cases) in squamous cell carcinoma. None of the patients with small cell carcinoma (34 cases) had NBTE. Eleven of the 142 patients had pathologically proved disseminated intravascular coagulation (DIC), and 4 of the 11 patients (36\%) also had NBTE. There was significant correlation between DIC and NBTE $(p<0.01)$. Seven of the 11 patients with NBTE had systemic thromboembolism mostly accompanied by infarction. Organs with thromboembolism were as follows: spleen ( 7 cases), brain ( 5 cases), kidneys ( 4 cases), heart (3 cases), and mesentery (2 cases). Multiple, hemorrhagic cerebral infarction (4 cases) was fatal. Myocardial infarction and peritonitis caused by mesenteric arterial embolization also contributed to death. The present study revealed that NBTE occasionally occured in patients with lung cancer and that systemic thromboembolism due to NBTE affected prognosis of the patients. The authors stress that clinicians should keep in mind the features and significance of NBTE in treating patients with lung cancer. 